\title{
The WTO and the Rights of the Individual
}

The Marrakesh Agreement Establishing the World Trade Organization (WTO) is silent regarding its relationship to the individual. ${ }^{1}$ One might presume that an international organization set up to emancipate trade could have no purpose other than upholding trading rights of private actors. But the WTO was not established to achieve "free trade". That goal is absent from the Marrakesh Agreement. Instead, the goals of the Agreement are "reciprocal and mutually advantageous arrangements directed to the substantial reduction of tariffs and other barriers to trade" and the "elimination of discriminatory treatment in international trade relations". 2 The term "reciprocal arrangements" makes clear that the focus of the Marrakesh Agreement is not on the individual trader, but rather on the meshing of governmental trade policies. This is confirmed by the object of the quoted provision, namely, "international trade relations". A visitor from another planet who takes a quick look at the Marrakesh Agreement could draw an erroneous conclusion about the Earth's economy. The visitor could infer that international trade is carried on between governments (or between nations) and that the intended beneficiaries of the Marrakesh Agreement are the government Members of the WTO.

Such a hasty inference would be wrong however. Although the subjects of the Marrakesh Agreement are the governments, a closer look at the multilateral trading system shows that

*Attorney, Wilmer, Cutler \& Pickering, Washington, D.C. The views expressed are those of the author.

${ }^{1}$ Marrakesh Agreement Establishing the World Trade Organization [hereinafter Marrakesh Agreement], in: World Trade Organization, The Legal Texts. The Results of the Uruguay Round of Multilateral Trade Negotiations. All WTO agreements discussed here are reprinted in this volume. ${ }^{2}$ Marrakesh Agreement, ibid., Preamble. 
individual economic actors are assimilated. Annexed to the Marrakesh Agreement are 17 interwoven trade agreements, most of which accord rights indirectly to the individual. This important feature of WTO law has not received the attention that it deserves.

In recent years, some commentators have called the WTO the "World Trade Constitution".3 Paralleling constitutions at the national level, the Marrakesh Agreement specifies decision rules and delineates the separation of powers among the WTO organs. In this way, the Marrakesh Agreement also resembles charters of other international agencies, such as the "Constitution" of the World Health Organization. But the constitutional underpinnings of the WTO go deeper than that. The WTO is constitution-like in reaching into the nation-state to guarantees rights to individuals.

The purpose of this article is to explore this little-noted dimension of international economic law. The article proceeds as follows: Part I examines the way that WTO agreements mandate certain rights for the individual in national law. Part II looks at the limited way in which the WTO agreements provide procedural rights to individuals at the WTO. Part III discusses how the WTO's emerging jurisprudence expounds this new relationship and interprets WTO rules in light of the needs of economic actors. Part IV proposes ways that a new WTO trade round could build on these developments in order to strengthen private rights.

By "economic actor", I mean an actor participating in the market and pursuing his, her or its self-interest. Such actors can be natural persons, business corporations, partnerships, cooperatives or labor unions. They operate as producers, consumers, service providers, exporters or importers.

\footnotetext{
${ }^{3}$ See, e.g., Ernst-Ulrich Petersmann: The WTO Constitution and Human Rights, in: Journal of International Economic Law, Vol. 3, No. 1, 2000, pp. 19-25; John O. McGinnis \& Mark L. Movsesian: The World Trade Constitution, in: Harvard Law Review, Vol. 114, No. 2, 2000, pp. 511-605. In 1997, then WTO Director-General Renato Ruggiero was quoted as stating that "We are writing the constitution of a single global economy". Kevin Danaher: Trade is a "we the people" decision not to be left to back-room, in: Christian Science Monitor, 19 September 1997, p. 18.
} 
Larger economic actors are probably better able to take advantage of these WTO rights than smaller actors are.

\section{Individual Rights in National Law}

Before discussing the WTO, one should say a brief word about individual rights in law. The insight that law undergirds and promotes an efficient market can be traced back to the ancients. In modern international law, the idea that governments have a common interest in the substantive rights accorded to individuals in other countries first triumphed in the establishment of the International Labor Organization in 1919. In that year, the ILO Maternity Convention provided that a woman "shall have the right to leave her work if she produces a medical certificate stating that her confinement [for childbirth] will probably take place within six weeks". ${ }^{4}$ International prescription of procedural rights within domestic law came a few years later. In 1927, the ILO Sickness Insurance Convention directed governments to grant a "right to appeal" to an applicant in case of a dispute. ${ }^{5}$ In 1933, the ILO Compulsory Old-Age Insurance Convention directed governments to provide individuals and employers a right to appeal to "special tribunals". ${ }^{6}$ Attention to procedural rights is the leitmotif of the "rule of law" in a regulated economy. Whenever an agency or bureaucrat is authorized to make a decision affecting an economic actor, the rule of law provides for an appeal to a higher entity to complain against arbitrary action or self-dealing.

${ }^{4}$ Convention Concerning the Employment of Women Before and After Childbirth, No. 3, 1919, Article 3(b).

${ }^{5}$ Convention Concerning Sickness Insurance for Workers in Industry and Commerce and Domestic Servants, No. 24, 1927, Article 9.

${ }^{6}$ Convention Concerning Compulsory Old-Age Insurance for Persons Employed in Industrial or Commercial Undertakings, in the Liberal Professions, and for Outworkers and Domestic Servants, No. 35, 1933, Article 11. (This Convention has been shelved by the ILO.) 
With that as background, this article turns to new developments wrought by the Uruguay Round. The WTO agreements comprise a system of obligations and rights for member governments. None of these obligations applies directly to individual actors. With one exception, no rights exist for economic actors within the WTO. Nevertheless, individuals secure rights indirectly from the WTO.

\section{Substantive Economic Rights}

The WTO gives economic actors an entitlement to substantive rights in domestic law. The two biggest gains came in the Agreement on Trade-Related Aspects of Intellectual Property Rights (TRIPS) and the General Agreement on Trade in Services (GATS). By a substantive right, I mean a property right or a legal guarantee of an opportunity to an economic actor. Such positive rights are a new feature of the multilateral trading system. They were not present in the General Agreement on Tariffs and Trade (GATT) of 1947.

The TRIPS Agreement requires governments to create and grant intellectual "property rights" to the nationals of other WTO member governments. ${ }^{7}$ In doing so, the drafters anticipated that these rights would probably also be granted to domestic persons because it would be impolitic for a government to give greater rights to aliens than to citizens. So economic actors may gain these rights not only in foreign countries, but also in their own.

TRIPS is a broad, yet single-minded regime. It accords exclusive property rights for copyrights, trademarks, geographical indications, industrial designs, patents, integrated circuits, and undisclosed information. ${ }^{8}$ The "right holders" are permitted to collect rents and to prevent others

\footnotetext{
${ }^{7}$ WTO Agreement on Trade-Related Aspects of Intellectual Property Rights [hereinafter TRIPS], Articles 1.3, 2.1, 9.1, 9.2, 10.2, 11, 14.2, 16.1, 25.1, 27.1, 35. TRIPS also requires governments to treat foreigners no less favorably than nationals. Ibid., Article 3.1.

${ }^{8}$ Developing countries are given extra time to meet these requirements. TRIPS Articles 65.4, 66.1.
} 
from infringing on their privilege for specified periods. These periods are lengthy; for example, an inventor is given a patent for 20 years. ${ }^{9}$ Although one of the objectives of TRIPS is to promote technological innovation, WTO member governments are not free to experiment with other approaches that avoid the inefficiencies entailed by a government-established monopoly. ${ }^{10}$

The GATS applies the traditional most-favoured-nation (MFN) and national treatment principles, but does so with a twist. In the GATT, the obligations of MFN and national treatment apply to products. ${ }^{11}$ But in GATS, these principles are also applied to economic actors, namely "service suppliers". ${ }^{2}$ The MFN requirement states that a government shall accord to services and service suppliers of other WTO member countries treatment no less favorable than accorded to like services or service suppliers of any other country. ${ }^{13}$ The national treatment provision requires that a government treat foreign services and service suppliers no less favorably than like domestic services and service suppliers in the sectors prescribed in that government's schedule of concessions. ${ }^{14}$

The innovator and service supplier do not acquire these substantive rights directly from TRIPS and GATS, but rather from governments via the implementation of their WTO obligations. Thus, if the treaty obligation is not fulfilled, an economic actor does not have a cause of action at the WTO.

\section{${ }^{9}$ TRIPS Article 33.}

${ }^{10}$ TRIPS Article 7 (Objectives). Of course, governments can grant these rights and then buy them back with taxpayer funds. TRIPS Article 27.3(b) does permit experimentation for the legal protection of plant varieties.

${ }^{11}$ General Agreement on Tariffs and Trade [hereinafter GATT], Articles I, III.

${ }^{12}$ Werner Zdouc: WTO Dispute Settlement Practice Relating to the GATS, in: Journal of International Economic Law, Vol. 2, No. 2, 1999, pp. 295, 324-327.

${ }^{13}$ General Agreement on Trade in Services [hereinafter GATS], Article II:1. Service suppliers can be natural persons. GATS Articles I:2(d), XXVIII(k).

\section{${ }^{14}$ GATS Article XVII: 1.}


Its only recourse would be to petition the government denying the right, or to lobby its own government to lodge a complaint at the WTO.

Because the substantive rights are extended only indirectly to individuals, the WTO can easily disobligate a government to respect these core rights. This can occur through the WTO dispute settlement system. To simplify a complex process, if a defendant government loses a case before a WTO panel and then fails to bring its practices into compliance with WTO rules by the required date, the winning plaintiff can gain WTO authorization to impose a sanction against the scofflaw defendant government. This is what happened in the "Bananas" dispute in 1999, when the U.S. government got WTO approval to levy high tariffs on products from the European Communities. In 2000 , for the first time, the WTO permitted a withdrawal of intellectual property rights to be used as a remedy. Specifically, the WTO gave the Government of Ecuador go-ahead to suspend its TRIPS obligations to the European Communities. ${ }^{15}$ In giving the go-ahead, the WTO arbitrators pointed out that this could abridge the private rights of individuals in Europe. ${ }^{16}$ Yet these private rights were trumped by the need for the WTO dispute settlement system to approve a sanction on the Communities.

\section{Procedural Rights}

To assist individual economic actors in gaining the benefits of WTO agreements, the drafters established numerous procedural and administrative requirements to be met by member governments. Many of these requirements provide a indirect right to an economic actor to seek

\footnotetext{
${ }^{15}$ European Communities - Regime for the Importation, Sale and Distribution of Bananas - Recourse to Arbitration by the European Communities Under Article 22.6 of the DSU, Report of the Arbitrators [hereinafter Ecuador Arbitration], 24 March 2000, WT/DS27/ARB/ECU, paragraphs 141, 144, 173(d). So far Ecuador has not exercised this retaliation authority.

${ }^{16}$ Ecuador Arbitration, paragraph 157.
} 
relief, to submit comments to a national agency, or to appeal adjudicatory rulings. These are "due process" rights. Unlike the substantive economic rights discussed above, these procedural rights may apply to domestic actors, in addition to foreign actors.

The idea of using a trade treaty to mandate procedural rights did not originate in the Uruguay Round. It was part of GATT Article X written in 1947. Most notably, GATT Article X:3(b) requires each party to maintain "judicial, arbitral or administrative tribunals or procedures for the purpose, inter alia, of the prompt review and correction of administrative action relating to customs matters". ${ }^{17}$ Furthermore, this provision requires such tribunals to be independent of the administering agency, and notes that appeals can be lodged by "importers." GATT Article X also contains a sunshine provision calling for the prompt publication of trade laws, regulations, and administrative rulings in order to enable both governments and "traders" to become acquainted with them. ${ }^{18}$

In requiring governments to accord such due process to economic actors, the original GATT laid the foundation for broader rights in the WTO agreements. Like the GATT, the WTO does not accord procedural rights directly to individuals (with one exception), but rather mandates that member governments do so. In four WTO agreements, the guarantee of such procedural rights is a central feature. These are the agreements on antidumping, subsidies, intellectual property, and services.

\footnotetext{
${ }^{17}$ GATT Article X:3(b).

${ }^{18}$ GATT Article X:1. In the Japan Film case, the WTO panel held that this provision applied both to rulings of general application and rulings in individual cases. Japan - Measures Affecting Consumer Photographic Film and Paper, Report of the Panel, 31 March 1998, WT/DS44/R, paragraph 10.388.
} 
The Antidumping Agreement requires governments to give numerous procedural rights to a domestic industry and to "interested parties". ${ }^{19}$ Governments must initiate an antidumping investigation upon the application of a domestic industry. ${ }^{20}$ Dumping is an attempt to sell an exported product for less than its comparable sale price in the exporting country. When dumping causes material injury to domestic producers, the importing government may seek to prevent the imports by levying an antidumping duty. The Antidumping Agreement is not perfectly clear as to whether the prescribed procedures must be carried out by all WTO member governments, or only by those governments that utilize antidumping measures.

Once it begins an antidumping investigation, a government incurs many procedural duties. The key duties are: (1) to give notice of the investigation to the public and to interested parties; (2) to allow interested parties an ample opportunity to present evidence and to defend their interests; (3) when an exporter has offered to raise prices in order to avoid an antidumping penalty, to give the exporter a reason if such offer is rejected and to allow the exporter to make comments thereon; (4) to offer judicial review, and (5) to give interested parties the right to seek sunset review of the continued need for an antidumping duty, and then to terminate the duty if no longer needed. ${ }^{21}$ Interested parties include: the government of the country of export; the foreign exporter or producer; the importer; a trade or business association whose members are producers, exporters, or importers of the product under investigation; the producer of the competing product in the country

\footnotetext{
${ }^{19}$ Several of these provisions were also in the Tokyo Round Antidumping Code. See Agreement on Implementation of Article VI of the General Agreement on Tariffs and Trade, 30 June 1967, GATT, Basic Instruments and Selected Documents, Supplement Vol. 15, p. 24.

${ }^{20}$ WTO Agreement on Implementation of Article VI of the General Agreement on Tariffs and Trade 1994 [hereinafter Antidumping Agreement], Article 5.1. Footnote 14 explains that employees may also instigate an investigation.

${ }^{21}$ Antidumping Agreement, Articles 6.1, 12.1, 12.2 (Notice); 6.2, 6.9 (Defense), 8.3 (Undertakings), 13 (Judicial Review), 11.2 (Sunset Review). The discipline on Undertakings is limited to "where practicable" and "to the extent possible".
} 
of importation; and an association whose members produce the like product in the country of importation. $^{22}$ The procedural rights for interested parties to seek sunset review is especially noteworthy as this process could be considered rulemaking rather than adjudication.

The Agreement on Subsidies and Countervailing Measures (SCM) contains analogous provisions regarding the investigation of foreign government subsidies and the imposition of countervailing duties. ${ }^{23}$ Because they closely track the Antidumping provisions, they will not be detailed here. In a few areas, however, the SCM Agreement goes beyond what is in the Antidumping Agreement. First, under SCM, the investigating authority can make a decision only on the basis of information in the written record which was available to interested parties participating in the investigation. ${ }^{24}$ Second, governments agree to establish procedures to take due account of representations made by interested domestic parties (including consumers) who might be adversely affected by the imposition of a countervailing duty. ${ }^{25}$ Third, SCM makes clear that judicial review is available to all interested parties who participated in the administrative proceeding and are directly and individually affected. ${ }^{26}$ Finally, SCM requires every WTO member government to conduct a countervailing duty investigation upon the application of a domestic industry. ${ }^{27}$

\footnotetext{
${ }^{22}$ Antidumping Agreement, Article 6.11. In addition, the government must provide opportunities for industrial users of the product under investigation, and for representative consumer organizations, to provide information relevant to the investigation. Ibid., Article 6.12.

${ }^{23}$ WTO Agreement on Subsidies and Countervailing Measures [hereinafter SCM], Articles 10-23.

${ }^{24} \mathrm{SCM}$ Article 12.2.

${ }^{25}$ SCM Article 19.2.

${ }^{26} \mathrm{SCM}$ Article 23.

${ }^{27} \mathrm{SCM}$ Articles 11.1, 32.5.
} 
Governments are not obligated to impose countervailing duties, but they would seem to be obligated to commence an investigation upon a proper request. ${ }^{28}$

The TRIPS Agreement contains numerous procedural obligations on governments toward the holders of private rights. One key obligation is "Transparency". ${ }^{29}$ Laws and regulations must be published in such a manner as to enable governments and rights holders to become acquainted with them. ${ }^{30}$ Another key obligation is to establish an enforcement system. Every government must enable an economic actor to institute administrative or judicial proceedings against any infringement of his intellectual property rights. ${ }^{31}$ If imported goods are involved, the government must adopt a procedure to permit the right holder to ask the Customs Authorities to block the free circulation of a good lacking an authentic trademark or copyright. ${ }^{32}$ By emphasizing the need to domesticate TRIPS obligations into national law, and by providing for a private right of action, TRIPS may be perhaps the most self-enforcing of all the WTO agreements. ${ }^{33}$

\footnotetext{
${ }^{28} \mathrm{SCM}$ Article 19.2.

${ }^{29}$ TRIPS Article 63.1.

${ }^{30}$ In the India Patent Protection case, the panel had held that "There must be a guarantee that the public - including interested nationals of other WTO Members - is adequately informed" about patent administration practices. India - Patent Protection for Pharmaceutical and Agricultural Chemical Products, Report of the Panel, 5 September 1997, WT/DS50//R, para. 7.42.
}

${ }^{31}$ TRIPS Articles 22.2, 23.1, 26.1, 28.1, 31(i), 39.2, 41, 42, 46.

${ }^{32}$ TRIPS Article 51. This provision implies that WTO member governments cannot have open borders and must employ Customs Authorities.

${ }^{33}$ TRIPS Articles 41.1, 67. Yet as one commentator notes, there may be few private parties in a country that have an incentive to enforce TRIPS obligations in national tribunals. Laurence R. Helfer: Adjudicating Copyright Claims Under the TRIPS Agreement: The Case for a European Human Rights Analogy, in: Harvard International Law Journal, Vol. 39, No. 2, 1998, pp. 357, 398. 
The GATS requires governments to accord due process to foreign economic actors. ${ }^{34}$ Specifically, each government must maintain "judicial, arbitral or administrative tribunals or procedures which provide, at the request of an affected service supplier, for the prompt review of, and where justified, appropriate remedies for, administrative decisions affecting trade in services", ${ }^{35}$ When prior authorization is required for the supply of a service, the government must give the applicant a decision within a reasonable period of time and inform the applicant as to the status of the application for authorization. ${ }^{36}$ In the "Reference Paper" for Basic Telecommunications Services, the subscribing governments commit to give a service supplier recourse to an "independent domestic body" in order to resolve disputes regarding interconnection with a major supplier. ${ }^{37}$ One other provision in GATS should be noted even though it does not confer a right: The GATS directs governments to work in cooperation with relevant intergovernmental and nongovernmental organizations towards the adoption of common international standards for setting qualifications of service suppliers. ${ }^{38}$

The attention to economic actors is less central in other WTO agreements, but still an important feature. The Safeguards Agreement requires governments, when commencing a safeguard investigation, to give public notice and to hold hearings in which importers, exporters and other interested parties can provide evidence and respond to the presentations of other parties. ${ }^{39}$ The

\footnotetext{
${ }^{34}$ The requirements in this paragraph apply only to governments that have made specific commitments in their schedules on services.

${ }^{35}$ GATS Article VI:2(a).

${ }^{36}$ GATS Article VI:3.

${ }^{37}$ European Communities, Schedule, WTO Doc. GATS/SC/31/Suppl. 3.

${ }^{38}$ GATS Article VII:5.

${ }^{39}$ WTO Agreement on Safeguards, Article 3.1.
} 
Customs Valuation Agreement requires governments to establish in law the right of the importer to appeal a determination of customs value. ${ }^{40}$ The Rules of Origin Agreement provides that an exporter or importer may ask a government for an official assessment of the origin of a good. ${ }^{41}$ The Agreement on the Application of Sanitary and Phytosanitary Measures (SPS) directs governments to provide a "reasonable interval" between the publication of a new regulation and its entry into force in order to provide time for "producers" to adapt their products and methods of production. ${ }^{42}$ The Agreement on Technical Barriers to Trade (TBT) requires governments, when introducing a new technical regulation, to publish a notice so as to enable interested parties to become acquainted with the regulation, and allow a "reasonable interval" before the regulation enters into force unless urgent circumstances exist. ${ }^{43}$ Attached to the TBT Agreement is a binding Code of Good Practice for standardizing bodies. ${ }^{44}$ The Code goes further than TBT in calling for interested parties to be given a 60 -day period for the submission of comments. ${ }^{45}$ The standardizing body is directed to "take into account" the comments, and to reply if requested. ${ }^{46}$ Finally the Agreement on Government

\footnotetext{
${ }^{40}$ WTO Agreement on Implementation of Article VII of the General Agreement on Tariffs and Trade 1994, Articles 11.1, 11.2. Note that in 1947, GATT Article VII:5 provided that the methods for determining value should be "given sufficient publicity to enable traders to estimate, with a reasonable degree of certainty, the value for customs purposes". This is a transparency provision.

${ }^{41}$ WTO Agreement on Rules of Origin, Articles 2(h), 3(f). This assessment is to be provided as soon as possible but no later than 150 days. Moreover, it must be reviewable by an independent tribunal.

${ }^{42}$ WTO Agreement on the Application of Sanitary and Phytosanitary Measures [hereinafter SPS], Article 7, Annex B, paragraph 2. An exception exists for urgent circumstances.

${ }^{43}$ WTO Agreement on Technical Barriers to Trade [hereinafter TBT], Articles 2.9.1, 2.10, 2.12.

${ }^{44}$ The Code of Good Practice for the Preparation, Adoption and Application of Standards is Annex 3 of the TBT Agreement. TBT Article 4 makes the Code binding on central government standardizing bodies. In the TBT lexicon, "regulations" are mandatory, while "standards" are not mandatory. TBT Annex 1.

${ }^{45}$ TBT Code of Good Practice, paragraph L.

${ }^{46}$ Ibid., paragraph N.
} 
Procurement requires parties to establish procedures to enable suppliers to challenge alleged breaches of the Agreement. ${ }^{47}$ The challenges are to be heard by a domestic court or by an independent review body.

\section{Individual Rights at the WTO}

Part II of this article addresses another new aspect of the world trading system, the extension of procedural rights directly to the economic actor. Compared to the numerous provisions discussed above, this facet of WTO constitutionalism is only thinly developed. Thus, Part II is short.

This novel feature emerged in the Agreement on Preshipment Inspection (PSI). Preshipment inspection verifies the quality, quantity, price, and customs classification of goods. Some governments mandate that goods be inspected before inward shipment. The PSI Agreement obligates those governments to require the inspection entity to make available a grievance procedure for exporters. ${ }^{48}$ Then, two working days after such a grievance is lodged, either the exporter or the inspector may refer the dispute to the "Independent Entity". ${ }^{49}$ The WTO established the Independent Entity in 1995, in cooperation with the International Federation of Inspection Agencies and the International Chamber of Commerce. ${ }^{50}$ If such referrals occur, the Independent Entity will

\footnotetext{
${ }^{47}$ Agreement on Government Procurement, Article XX. WTO Members are not required to join this agreement. To increase adherence to transparency in procurement, a separate agreement could be negotiated. Sue Arrowsmith: Towards A Multilateral Agreement on Transparency in Government Procurement, in: International and Comparative Law Quarterly, Vol. 47, No. 4, 1998, pp. 793-816.

${ }^{48}$ WTO Agreement on Preshipment Inspection [hereinafter PSI Agreement], Article 2.21.

${ }^{49}$ PSI Agreement, Article 4.

${ }^{50}$ Operation of the Independent Entity Established under Article 4 of the Agreement on Preshipment Inspection, WTO Press Release, 9 February 1996.
} 
set up an arbitral panel whose decisions are binding on the exporter and inspector. ${ }^{51}$ The role of the panel is to decide whether the parties have complied with the PSI Agreement. ${ }^{52}$

This review procedure gives an economic actor - the exporter - a procedural right of action under WTO rules. The exporter can bring a grievance to the WTO. The exporter's claim would be that the agent of the importing government (i.e., the preshipment inspector) is violating the PSI Agreement. In other words, the individual is empowered to enforce international trade law through the WTO's Independent Entity. So far, this unique provision has not been tested.

\section{Jurisprudence on the Individual}

Although the WTO dispute settlement system considers only disputes between governments, all such disputes reflect rivalry among private economic actors. A dispute that is exclusively between sovereign governments is imaginable -- for example, two state trading entities -- but no such cases have arisen in the WTO. Despite the centrality of private actors in trade disputes, these actors are not explicitly acknowledged in the WTO Dispute Settlement Understanding.

Nevertheless, WTO panels are beginning to lift the governmental veil to see the economic actors who are the real stakeholders in a dispute. The leading case is United States Section 301 where the panel held that a hypothetical application of a controversial U.S. trade law did not violate WTO rules. ${ }^{53}$ The panel agreed with the plaintiff, the European Communities, that a prospective implementation of the "Section 301" law could be a current violation of WTO rules, but in this

\footnotetext{
${ }^{51}$ PSI Agreement, Article 4(h).

${ }^{52}$ PSI Agreement, Article 4(f).

${ }^{53}$ Sections 301-310 of the Trade Act of 1974, Report of the Panel, 22 December 1999, WT/DS152/R, paragraph 8.1 [hereinafter Section 301 Panel Report]. Section 301 authorizes the U.S. Trade Representative to investigate foreign trade practices that burden U.S. commerce and to retaliate against foreign countries.
} 
instance, the panel accepted the U.S. government's defense that the U.S. Trade Representative did not have discretion to impinge WTO law in the manner alleged. ${ }^{54}$

The pregnant holdings of the panel vis-à-vis the individual economic operator came in the analysis of why a measure of general applicability not yet enforced can still be actionable in the WTO. The panel begins its analysis by pointing out that the "GATT/WTO did not create a new legal order the subjects of which comprise both contracting parties or Members and their nationals". ${ }^{55}$ But then the panel reflects on the role of the WTO, and surmises that

... it would be entirely wrong to consider that the position of individuals is of no relevance to the GATT/WTO legal matrix. Many of the benefits to Members which are meant to flow as a result of the acceptance of various disciplines under the GATT/WTO depend on the activity of individual economic operators in the national and global market places. ${ }^{56}$

Then, building on this reasoning, the panel draws a significant, startling, conclusion. That is, "the multilateral trading system is, per force, composed not only of States but also, indeed mostly, of individual economic operators". ${ }^{57}$ The panel holds that the needs of such operators should be a factor in determining whether a particular WTO provision is being violated by a government. ${ }^{58}$ According to the panel, exposing an individual operator to the risk of WTO inconsistent action by a government can itself constitute a WTO violation because of the "chilling effect" and loss of "confidence" by such operators. ${ }^{59}$

\footnotetext{
${ }^{54}$ Section 301 Panel Report, paragraphs 7.96, 7.109, 7.125, 7.136. The members of the panel were David Hawes, Terje Johannessen, and Joseph Weiler.

${ }^{55}$ Ibid., paragraph 7.72 .

${ }^{56}$ Ibid., paragraph 7.73 .

${ }^{57}$ Ibid., paragraph 7.76 .

${ }^{58}$ Ibid., paragraphs 7.90, 7.94, 7.167.

${ }^{59}$ Ibid., paragraphs 7.91, 7.93, 7.94.
} 
The Section 301 decision is startling because, through its careful logic and citation of precedents, the panel looks behind the curtain of WTO dispute settlement to reveal more than a clash of sovereigns. The panel suggests that in considering whether one sovereign has violated its treaty obligation to the other, the judge can properly consider not just the interests of the sovereigns, but also the private actors. That's what the panel means in saying that economic operators are part of the world trading system. The WTO dispute settlement system will surely build on this insight in the future, as economic operators push governments to comply with their obligations.

The panel's broad statements about the marrow of WTO law may seem jarring because the role of international judges in treaty interpretation is less developed than the role of national judges in interpreting a constitution. But the enhanced role for the WTO judge is a manifestation of the evolution of world trade law from its simpler beginnings in the GATT. This process was foreseen by a few commentators. For example, Victoria Curzon Price -- building on insights of Friedrich A. von Hayek -- predicted that the process of articulating written trade rules will produce new rules. ${ }^{60}$

The Section 301 decision was not appealed, and thus was not affirmed by the Appellate Body. The question of what duties a government owes to economic actors arose in two earlier decisions. In the Gasoline case, the Appellate Body adjudged the United States to be violating the GATT because U.S. environmental officials took into account the regulatory costs of domestic refiners while disregarding the costs incurred by foreign refiners. ${ }^{61}$ In the India Patent Protection case, the Appellate Body narrowed the judgment of the first-level panel, and stated that "we do not agree with the Panel that the legitimate expectations of Members and private rights holders concerning

\footnotetext{
${ }^{60}$ Victoria Curzon Price: New Institutional Developments in GATT, in: Minnesota Journal of Global Trade, Vol. 1, No. 1, 1992, pp. 87, 109-110.

${ }^{61}$ United States - Standards for Reformulated and Conventional Gasoline, Report of the Appellate Body, 29 April 1996, WT/DS2/AB/R, p. 28.
} 
conditions of competition must always be taken into account in interpreting the TRIPS Agreement". 62

\section{Strengthening Private Rights in the New Trade Round}

Although governments sought to launch a new trade round in Seattle at the end of 1999, this effort failed for many reasons, one of which was a lack of enthusiasm by citizens in many countries. Despite the advantages to private actors of freer trade, the WTO has failed to explain its constructive role to the public. Indeed, public opinion is often skeptical of the WTO, and many groups view it unfavorably.

In my view, the biggest public relations problem faced by the WTO is that its state-centricity impedes its ability to explain the benefits of trade rules. More awareness of how the WTO indirectly confers legal rights to individuals, as detailed above, could enhance the WTO in public esteem. Politicians should seek to "sell" the new round, in part, as a way to protect individual actors against arbitrary bureaucratic action. In other words, rather than selling the WTO as an exercise in deepening commitments among governments, politicians should be trumpeting the ways that the WTO improves the legal status of the individual. Part IV of the article proposes that the new round address substantive rights in national law, procedural rights in national law, procedural rights at the WTO, and public perceptions.

\section{Substantive Economic Rights}

Ideally, the WTO would prohibit all protectionist policies and mandate a presumption in favor of a right of individuals to import and export. ${ }^{63}$ Yet promoting free trade so unabashedly would be

\footnotetext{
${ }^{62}$ India - Patent Protection for Pharmaceutical and Agricultural Chemical Products, Report of the Appellate Body, 19 December 1997, WT/DS50/AB/R, para. 48.
} 
anathema for most WTO member governments. So one should consider other ways to strengthen economic rights.

One proposal is to enlist the WTO in the campaign to address the "digital divide" by emphasizing the issue of internet access. This could be done in the ongoing GATS negotiations. A recent study by Reporters Sans Frontières found that 45 countries severely curtail internet access for nationals. The WTO might start with that high-profile regulatory problem and then work to assure market access and interconnection for internet service providers seeking to compete in new markets. In this way, the WTO could champion better economic opportunities for consumers (and service suppliers).

Another idea is to repeal the provision in the WTO Dispute Settlement Understanding that permits a plaintiff government winning a case to dishonor the intellectual property rights of the losing defendant government when that government fails to comply with a WTO judgment. ${ }^{64}$ As noted above, a WTO panel recently authorized Ecuador to flout intellectual property rights of European Union nationals. This is a very disturbing legal development that punctures holes in the TRIPS Agreement and contradicts the rationale for including TRIPS within the trading system. Furthermore, in authorizing such action, the WTO encourages Ecuador and similarly situated

\footnotetext{
${ }^{63}$ The earliest constitution to prohibit protectionism was the Constitution (1861) of the Confederate States of America. This Constitution withheld power from Congress to levy any duty or tax to promote or foster any branch of industry.

${ }^{64}$ WTO Understanding on Rules and Procedures Governing the Settlement of Disputes [hereinafter DSU], Article 22.
} 
countries to ignore their pre-existing obligations under intellectual property conventions. ${ }^{65}$ The WTO should not be inducing and abetting such violations of economic rights. ${ }^{66}$

\section{Procedural Rights in National Law}

Although similar due process rights appear in several WTO agreements, these provisions are unlinked and the Marrakesh Agreement makes no attempt to articulate an overall purpose for them. This omission was a missed opportunity for Uruguay Round negotiators to explain to the public how WTO rules protect individual actors against arbitrary governmental action both at home and in other countries. Governments deserve more credit than they have gotten for signing on to these obligations.

The next round should fill in this gap by making clearer the foundations for the emerging international administrative law on trade. ${ }^{67}$ A country may be concerned about the administrative procedures used in other countries for at least three reasons. First, a government cannot receive the anticipated value of a trade negotiation unless its nationals get the promised treatment in other markets, and can use foreign tribunals to complain about an arbitrary denial of that treatment. If a government wants its nationals to have that opportunity in foreign countries, however, it must give foreign nationals equivalent opportunities in domestic tribunals. Second, all countries have an interest in promoting better government practices in other countries because that will enable each country to enhance its comparative advantage and therefore lift total world income. A transparent,

\footnotetext{
${ }^{65}$ Ecuador Arbitration, paragraph 152.

${ }^{66}$ To be sure, TRIPS can be criticized for glorifying private interests over public interests. But the solution to that is to amend TRIPS, not to flout it.

${ }^{67}$ The term "International administrative law" has traditionally referred to the law governing the relationship between an inter-governmental organization and its staff. I use the term differently here to describe international supervision of the rulemaking and adjudication procedures employed by national agencies.
} 
fair system of administrative law is a key component of good practice because it can correct the mistakes made by bureaucrats. Third, the right of an individual to participate in decisionmaking that affects him enhances the legitimacy of the ensuing decisions.

The WTO provisions for procedural rights extend both to adjudication and to rulemaking. The adjudication provisions are far more developed however. For example, an individual actor with an interest in a new countervailing duty investigation has a right to receive notice, to present written evidence, to review the public docket, to be informed of the essential facts in time to defend its interest, to make a representation against the countervailing duty, to receive notice of preliminary and final determinations, and to seek judicial review. ${ }^{68}$ On the other hand, if a government proposes to rewrite its countervailing duty law or the accompanying regulations, the SCM Agreement does not accord any procedural rights to the economic actor. In other words, the SCM Agreement does not require prior notice or the opportunity for public comment. This is so even when a government changes its countervailing duty law in response to a decision by the WTO Dispute Settlement Body. The closest the SCM agreement gets to rulemaking is that it gives a private actor an opportunity to comment on a governmental review of whether a countervailing duty should be discontinued. ${ }^{69}$

Private actors need notice-and-comment provisions on national rulemaking with regard to both trade and domestic regulation. ${ }^{70}$ GATT Article X:2 provides for advance notice of general trade

\footnotetext{
${ }^{68} \mathrm{SCM}$ Articles 12.1, 12.1.13, 22.1, 22.2 (Notice of Investigation); 12.1, 12.10 (Evidence); 12.3 (Docket); 12.8 (Defend Interest); 19.2 (Representation); 22.3 (Notice of Determinations); 23 (Judicial Review).
}

${ }^{69} \mathrm{SCM}$ Article 21.4.

${ }^{70}$ James Cameron and Karen Campbell: Challenging the Boundaries of the DSU Through Trade and Environment Disputes, in: Cameron and Campbell (eds.), Dispute Resolution in the World Trade Organisation, London 1998, pp. 204, 227. For a good analysis of notice-and-comment from a comparativist perspective, see Francesca Bignami: The Democratic Deficit in European Community Rulemaking: A Call for Notice and Comment in Comitology, in: Harvard International Law Journal, Vol. 40, No. 2, 1999, pp. 451-515. 
regulations, but does not accord an opportunity to give comments. ${ }^{71}$ The other WTO agreements regarding trade policy (e.g., safeguards) also fail to provide individuals any right to comment. Two of the WTO agreements supervising domestic regulation -- GATS and SPS -- lack any notice-andcomment process for economic actors. ${ }^{72}$ Another agreement on domestic regulation, TBT, does provide for notice-and-comment. This requirement is contained in the Code of Good Practice which calls for giving interested parties a 60-day period for the submission of comments on proposed standards. The TBT does not require a notice-and-comment process for the adoption of "regulations", however, even though the mandatory nature of regulations makes such communication more important than it is for non-mandatory "standards".

Notice-and-comment requirements would be particularly useful in WTO agreements dealing with domestic regulation. For example, a government contemplating a new sanitary health regulation should open itself up to criticism by private economic actors as to whether the proposed measure is too stringent or too lax. A vibrant public comment procedure could head off the adoption of an unnecessary regulation that can lead to a trade dispute. The WTO should require governments to give a public response to any comments received.

The prospects for putting this topic on the agenda of the next round are uncertain. ${ }^{73}$ Some WTO delegates would surely protest that a government's decisionmaking is too intrinsically

\footnotetext{
${ }^{71}$ As Friedl Weiss has noted, the Charter for the International Trade Organization (1948) called on governments to provide suitable facilities for traders directly affected by trade laws, regulations, and rulings "to consult" with government authorities. This provision was in Article 38.3(a). The Charter never went into force. Friedl Weiss: From Havana to Marrakesh: Treaty Making for Trade, in: J. Klabbers and R. Lefeber (eds.), Essays on the Law of Treaties, The Hague 1998, pp. 155, 163.

${ }^{72} \mathrm{SPS}$ does contain a requirement to give notice to other governments and to allow them to comment. SPS Annex B, paragraph 5. Like many of the annexed agreements, SPS also calls on governments to notify the WTO when it employs certain measures.

${ }^{73}$ During the Uruguay Round, the Swiss Government proposed an expansion of GATT Article X to require a fair hearing and a reasoned decision. The proposal explained that improving the minimum
} 
domestic to become a topic for international minimum standards. Yet governments have agreed on the norm of public participation in environmental policymaking, most notably in the Åarhus Convention of $1998 .^{74}$ This Convention commits governments to provide adequate and timely public notice of pending decisions and to put in place a procedure for the public to submit comments in writing or at a public hearing. ${ }^{75}$ Governments have also provided for public participation in labor treaties. For example, the ILO Convention on Workers with Family Responsibilities states that employer and worker organizations "shall have the right to participate, in a manner appropriate to national conditions and practice, in devising and applying measures to give effect to the provisions of this Convention". ${ }^{76}$ In early 2001, three former Directors-General of the GATT/WTO issued a joint public statement addressing the current state of the multilateral trading system. Among their recommendations was: "Where they have not already done so, we would encourage all governments to open up trade policy debate at the national level."

\section{Procedural Rights at the WTO}

As noted above, private actors lack standing to lodge complaints in the WTO. This contrasts with some international human rights courts (such as the European Court of Human Rights) where

procedural rights of private actors would "render the domestic branch of the functioning of GATT more effective in reality". Switzerland, Draft Proposal on GATT Obligations with Respect to Rules and Procedural Rights in Domestic Law, MTN.GNG/NG14/W/43, 9 July 1990. This proposal was not adopted.

${ }^{74}$ Jonas Ebbesson: The Notion of Public Participation in International Environmental Law, in: Yearbook of International Environmental Law, Vol. 8, 1997, pp. 51-97.

${ }^{75}$ Convention on Access to Information, Public Participation in Decision-making and Access to Justice in Environmental Matters, 1998, Articles 6-8.

${ }^{76}$ Convention concerning Equal Opportunities and Equal Treatment for Men and Women Workers: Workers with Family Responsibility, No. 156, 1981, Article 11. 
individuals can bring cases against governments. ${ }^{77}$ For the foreseeable future, however, the WTO is not going to give private actors a right to prosecute governments for violating world trade law.

One reform that is conceivable would be for the WTO to give private actors a right to defend themselves before a WTO panel. The need for this does not come up often. But when it does, the affected private actor lacks any right to respond. The best example is the Australia Leather case which will be discussed below. In a typical WTO case, there are private actors who will be affected depending on which government wins the case. Yet these effects are extrinsic to the panel's decision which is almost always focused on governmental behavior.

In the Australia Leather dispute, the U.S. government was successful in characterizing an Australian government grant to the leather producer Howe and Company as a prohibited export subsidy, in violation of the SCM Agreement. ${ }^{78}$ The panel did not give Howe any opportunity to argue that the grant to it was not an export subsidy. But that incapacity is normal. The WTO has adjudicated several export subsidy cases all of whom have stakeholders who are not heard from in during proceedings.

What was unusual, and troubling, in the Leather case was Howe's absence during the compliance review proceedings in 1999. The panel ruled that Australia had failed to comply because it had not required Howe to repay the subsidy to the government. ${ }^{79}$ This was the first time any GATT or WTO panel issued a judgment that would require a private actor to repay money to a

\footnotetext{
${ }^{77}$ Robert O. Keohane, Andrew Moravcsik, and Anne-Marie Slaughter: Legalized Dispute Resolution: Interstate and Transnational, in: International Organization, Vol. 54, No. 3, 2000, pp. 457, $462-66$.

${ }^{78}$ Australia - Subsidies Provided to Producers and Exporters of Automotive Leather, Report of the Panel, 25 May 1999, WT/DS126/R.

${ }^{79}$ Australia - Subsidies Provided to Producers and Exporters of Automotive Leather, Recourse to Article 21.5 of the DSU by the United States, Report of the Panel, 21 January 2000, WT/DS126/RW, paragraph 6.48 .
} 
government. In a previous GATT case, a government was directed to repay an antidumping duty erroneously collected from an importer, but there the private actor was being compensated. In Australia Leather, the private actor was to be billed. The panel acknowledged that its decision could result in "some interference with private rights", but this did not trigger any introspection by the panel. ${ }^{80}$ Given the important precedent being set in this case, which might be characterized as a WTO-required confiscation, it was unfortunate that the panel did not offer Howe an opportunity to present a defense. This could have easily been done since WTO rules give every panel the authority to seek information from any individual or body that the panel deems appropriate. ${ }^{81}$

If it becomes the regular practice of the WTO to require a private actor receiving a WTOinconsistent subsidy to repay the granting government, then the WTO will need procedures for assuring due process to the private actor. Adjudicating issues such as the value of the subsidy and the proper repayment schedule should not be done in the absence of the corporation whose assets are threatened with seizure. Even today, the WTO has failed to acknowledge the injustice to Howe which had not done anything wrong under Australian law or WTO law. Howe did not violate WTO law because the WTO does not impose any obligations on individuals.

When the Shipbuilding Agreement was negotiated in the Organization for Economic Cooperation and Development (OECD) in 1994, the governments recognized that private actors may need due process rights before panels in government-to-government dispute settlement. The Agreement provides that if a government seeks the remedy of collecting back from a shipbuilder the amount of benefit it received exceeding the terms of the Agreement, then that shipbuilder shall be

\footnotetext{
${ }^{80}$ Ibid. paragraph 6.23 .

${ }^{81}$ DSU Article 13.1.
} 
entitled to participate fully in the panel's proceedings. ${ }^{82}$ The WTO needs a similar procedural guarantee.

\section{Improving Public Perceptions}

Among the many reasons why public opinion undervalues the WTO is that the texts of the WTO agreements are often difficult to understand. One key problem is that these agreements are written in state-centric, mercantilist jargon that obfuscates who the beneficiaries of the WTO really are. Very little international trade today involves governments on both sides of the transaction. Yet several of the WTO agreements refer to "importing Members" or "exporting Members" as if the governments were doing the trading. ${ }^{83}$ The ordinary citizen will understandably not be enthusiastic about upholding rights for "importing Members". This suggests that one task of the next trade round should be to rewrite these confusing provisions. For example, the "importing Member" might be rewritten as "the government of the country whose private actors are seeking to import".

\section{Conclusion}

The Marrakesh Agreement and its annexes can be described as a treaty setting out the obligations of WTO member governments to each other, but this description is incomplete. One of the most important advances of the Uruguay Round was to extend world trade rules so that they reach into the nation-state to adjust the status of the individuals residing therein. This transformation of the GATT is an example of "institutional imagination and cautious

\footnotetext{
${ }^{82}$ Agreement Respecting Normal Competitive Conditions in the Commercial Shipbuilding and Repair Industry, 1994 (not in force), Articles 8.1, 8.3, 8.5, Annex IV.

${ }^{83}$ For example, see Antidumping Agreement Articles 2.5, 4.2, 6.11; TBT Articles 2.12, 5.9; SCM Articles 15.2, 18.5, 27.10.
} 
experimentation" called for by Jürgen Habermas in his discussion of the role of procedural law in satisfying the conditions of constitutional legitimacy. ${ }^{84}$

The Marrakesh Agreement addresses a kind of government failure that received very little attention in the GATT. The new target is discriminatory and arbitrary action against the economic actor. By embedding due process rights for individuals in national legal systems, the Uruguay Round establishes a "more viable and durable multilateral trading system". ${ }^{85}$ By providing a check against arbitrary government action, the WTO better enables the individual to compete in the global economy.

Although it is far from becoming a palladium of individual rights, the WTO fortifies the rights of economic actors. The best-known institutionalization of rights occurs in TRIPS which was partially based on existing treaties and partially sui generis. Far less known, though equally important, are the new procedural obligations instilled horizontally in many of the annexed WTO agreements. The obligations run from the WTO to governments, and then from governments to economic actors. These individual rights are most developed in TRIPS, SCM, and the Antidumping Agreements where, ironically, they empower individuals to prevent international trade that violates WTO norms. Yet the interests of the users and consumers of imports are not disregarded. Both the Antidumping and SCM agreements provide some beneficiaries of trade a right to participate in antidumping and countervailing duty adjudications.

Two features of the WTO qualify it as constitutional in the views of some commentators, but a third feature is just as important. The Marrakesh Agreement is constitutional in stating decision rules and allocating authority among WTO organs. Furthermore, the Agreement is constitutional in

\footnotetext{
${ }^{84}$ Jürgen Habermas: Between Facts and Norms, Cambridge, Massachusetts 1996 (translated by William Rehg), pp. 440-41.

${ }^{85}$ See Marrakesh Agreement Preamble.
} 
prescribing international rules that bind governments, and in defining those powers that are reserved to the national level. This article presents a third reason why the Marrakesh Agreement is constitutional: because it indirectly accords rights to individuals. At the national level, the WTO calls for private actors to have the right to participate in an adjudication that affects them. At the international level, the WTO sponsors the Preshipment Inspection Entity. Although narrow in scope, this Entity sets an important precedent.

In noting the constitutional features of the WTO, I am not suggesting that the WTO is functionally equivalent to a national constitution. The WTO lacks an associated demos to accord it legitimacy. ${ }^{86}$ Thus, the WTO draws its legitimacy from the consent of disconnected governments. But an organization like the WTO is more than a tool of political delegation. It is also an organism, enjoying international legal personality and the capacity to grow and change. If it can strengthen its connections to economic (and social) actors around the globe, the WTO will gain more vitality and public support.

The new relationship between the trading system and the individual actor is beginning to be recognized in WTO jurisprudence. The Section 301 panel cut through the fog by explaining that "it would be entirely wrong to consider that the position of individuals is of no relevance to the GATT/WTO legal matrix", and by pointing out that the multilateral trading system is "composed not only of States but also, indeed mostly, of individual economic operators". This holding has drawn little attention by the government delegates that run the WTO. I would venture to guess that if this particular proposition were put to a vote in the General Council of the WTO, it would be rejected by governments who want to preserve the WTO as a cozy club of trade bureaucrats. In

${ }^{86}$ Cf. Peter L. Lindseth: Democratic Legitimacy and the Administrative Character of Supranationalism: The Example of the European Community, in: Columbia Law Review, Vol. 99, No. 3, 1999, pp. 628-738. 
accordance with WTO procedures, however, the Section 301 decision was automatically adopted by the WTO Dispute Settlement Body. Thus, this cutting-edge decision will influence future WTO panelists and the invisible college of international trade law in the years ahead.

Because it enhances both due process and property rights of economic actors, the WTO is more than a commercial agreement; it is also a human rights agreement. In recent years, several commentators have advocated that the WTO pay more attention to human rights norms. For example, Raj Bhala in his trade law textbook writes that "If the GATT-WTO regime is a just one, in the sense of Kant or his modern-day disciples who defend liberal democratic theory, then the central focus of this regime must be on the protection and service of the individual". ${ }^{87}$ Ernst-Ulrich Petersmann explains that "the globalization of production, trade and economic markets cannot remain effective without a corresponding globalization of legal and institutional guarantees of individual freedom, non-discrimination, rule of law, access to courts and democratic government" ${ }^{88}$ In this article, I show how the trading system is already moving in the direction pointed to by Bhala and Petersmann because of the many ways that the WTO strengthens economic rights and requires national government to be more accountable to the individual.

\footnotetext{
${ }^{87}$ Raj Bhala: International Trade Law: Theory and Practice, New York, 2nd edition, 2001, p. 610.

${ }^{88}$ Ernst-Ulrich Petersmann: From "Negative" to "Positive" Integration in the WTO: Time for "Mainstreaming Human Rights" into WTO Law?", in Common Market Law Review, Vol. 37, No. 6, 2000, pp. 1363, 1375.
} 